\title{
Implementasi Pembelajaran pada Masa Lockdown bagi Lembaga PAUD di Kabupaten Lombok Timur
}

\author{
Khirjan Nahdi ${ }^{1}$, Sandy Ramdhani ${ }^{1}{ }^{凶}$, Riyana Rizki Yuliatin ${ }^{2}$, Yul Alfian Hadi ${ }^{3}$ \\ 1 Program Studi Pendidikan Bahasa dan sastra Indonesia Universitas Hamzanwadi \\ 2 Pendidikan Guru Pendidikan Anak Usia Dini, Universitas Hamzanwadi \\ 3 Pendidikan Seni Drama Tari dan Musik, Universitas Hamzanwadi \\ 4 Pendidikan Guru Sekolah Dasar, Universitas Hamzanwadi \\ DOI: $10.31004 /$ obsesi.v5i1.529
}

\begin{abstract}
Abstrak
Lembaga PAUD sebagai pelaksana proses pembelajaran berperan penting dalam pelaksanaan pembelajaran di rumah selama pandemi. Tujuan dari penelitian ini adalah untuk melihat implementasi pembelajaran di PAUD selama Pandemi Covid-19 dari Lembaga PAUD yang ada di Kabupaten Lombok Timur. Terdapat 30 sampel Lembaga PAUD dengan jenis penelitian kualitatif. Instrumen yang digunakan adalah wawancara, observasi, angket dan dokumentasi. proses analisis data menggunakan analisis miles \& Hubberman dengan triangulasi data. Tiga aktivitas utama yang digunakan dalam penerapan pembelajaran yaitu penugasan (A), Home Visit (B), Laporan Kegiatan Harian Anak (3). Ketiga aktivitas utama ini yang paling banyak digunakan oleh pihak Lembaga PAUD adalah Penugasan (A) dan kolaborasi Penugasan dengan Home Visit (AB), dan terdapat pula Lembaga yang menggunakan ketiga aktivitas kegiatan pembelajaran tersebut yaitu kolaborasi Penugasan, Home Visit dan Laporan Kegiatan Anak (ABC)
\end{abstract}

Kata Kunci: covid-19; lembaga paud; lockdown; belajar di rumah.

\section{Abstract}

Repeated Word PAUD institutions as the implementers of the learning process play an important role in implementing learning at home Repeated Word during the pandemic. The purpose of this study was to look at the implementation of learning in PAUD during the Covid19 pandemic from PAUD Institutions in East Lombok Regency. There are 30 samples of PAUD institutions with qualitative research types. The instruments used were interviews, observation, Quesionaire and documentation. The data analysis process uses miles \& Hubberman analysis with data triangulation. The three mainRepeated Word activities used for the application of learning are assignments (A), Home Visit (B), Children's Daily Activity Report (3). These three mainRepeated Word activities that are most widely used by PAUD institutions are Assignment (A) and Collaboration of Assignment with Home Visit (AB), and there are also institutions that use these three learning activities namely assignment collaboration, Home Visit and Child Activity Report (ABC)

Keywords: covid-19; paud institution; lockdown: learning; study at home.

Copyright (c) 2020 Khirjan Nahdi, Sandy Ramdhani, Riyana Rizki Yuliatin, Yul Alfian Hadi

$\triangle$ Corresponding author :

Email Address : Sandy160392@gmail.com (Jln TGKH Zainuddin Abdul Madjid no 132 Pancor,

Universitas Hamzanwadi

Received tanggal bulan tahun, Accepted tanggal bulan tahun, Published tanggal bulan tahun 


\section{PENDAHULUAN}

coronaviruses Disease 2019 (covid-19) merupakan virus yang sekarang ini menjadi permasalahan bagi seluruh dunia. World Health Organization (WHO) mengumumkan bahwa virus covid-19 merupakan pandemi di seluruh dunia karena jumlah negara yang terdampak sebanyak 213 negara dengan total kasus positif sekitar 3 juta di seluruh dunia dengan korban meninggal dunia mencapai 200 ribu orang (Covid19.go.id, 2020; kompas, 2020). Pandemi covid-19 ini juga menjadi sebuah permasalahan serius yang terjadi di Indonesia. Berdasarkan data terbaru dari tim gugus tugas penanganan Covid-19 republik Indonesia jumlah pasien positif covid-19 berjumlah 9132 dengan pasien meninggal berjumlah 723 orang (Covid19.go.id, 2020). Berdasarkan data tentang persebaran jumlah kasus pasien positif Covid-19 kemudian pemerintah Republik Indonesia mengambil kebijakan melalui Keppres no 11 tahun 2020 tentang Penetapan Kedaruratan Kesehatan Masyarakat Covid-19 yang menghasilkan pembatasan aktivitas bagi masyarakat yang kemudian dikenal dengan istilah Lockdown (Covid19.go.id, 2020; Keppres, 2020). Penerapan pembatasan aktivitas masyarakat untuk memutus penyebaran virus covid-19 berlaku diberbagai sector diantaranya Pendidikan, ekonomi, keagamaan, social dan kegiatan masyarakat lainnya. Salah satu sector yang paling dipengaruhi dengan adanya lockdown adalah Pendidikan. Proses kegiatan pembelajaran dari jenjang PAUD hingga Perguruan Tinggi lumpuh total bahkan kemendikbud mengeluarkan Surat Edaran No 4 tahun 2020 tentang pelaksanaan kebijakan Pendidikan di tengah Pandemi yang salah satu isinya membuat proses kegiatan pembelajaran dilaksanakan di rumah (KEmendikbud, 2020;).

semua jenjang Pendidikan tidak terlepas dari dampak pandemi covid-19. Pandemi covid-19 sangat berdampak besar terhadap Pendidikan di Indonesia, mulai jenjang PAUD, Sekolah Dasar, Sekolah Menengah, hingga perguruan tinggi menjadi terkendala dikarenakan pandemi covid-19 ini. Dampak adanya physical distancing dan social distancing memaksa pemerintah untuk melaksanakan proses Pendidikan dari rumah. Istilah "Belajar dari Rumah" untuk siswa dan "Bekerja dari rumah" untuk tenaga pendidik menjadi meluas (Kementerian Sekretariat Negara Republik Indonesia, 2020; Kemendikbud, 2020; Trubus, 2020). Permasalahan yang kemudian terjadi setelah diterapkannya physical distancing dan social distancing adalah merubah proses pembelajaran di sekolah menjadi belajar di rumah ini kemudian memberikan dampak yang signifikan terhadap perkembangan Pendidikan siswa. Pembelajaran yang selalu di kelas dengan berbagai metode pembelajaran baik konvensional maupun inovasi metode menjadi terhambat (Khadilkar et al., 2020; Mussardo, 2019; Uscher-Pines et al., 2018).

salah satu jenjang Pendidikan yang paling dipengaruhi oleh penerapan lockdown adalah jenjang Pendidikan Anak Usia Dini (PAUD). Dunia anak adalah dunia bermain dan berinteraksi dengan lingkungan baik lingkungan keluarga, masyarakat, dan sekolah (Ramdhani et al., 2019; Yuliastri, Nur Adiyah, ramdhani, 2018). Proses belajar anak terutama proses kegiatan pembelajaran di sekolah merupakan salah satu cara meningkatkan kemampuan aspek perkembangan anak, akan tetapi setelah pandemi covid-19 yang memaksa anak belajar di rumah sehingga membuat kegiatan terstruktur anak selama di sekolah guna mendukung tingkat pencapaian perkembangan anak menjadi terhambat. aktivitas-aktivitas anak yang selama ini terpaku di sekolah akhirnya Kembali ke proses Pendidikan dari orang tua dengan penerapan istilah belajar di rumah yang menciptakan proses Pendidikan yang bermakna

proses Pembelajaran identik dengan proses belajar sambil bermain dan bermain sambil belajar. Proses tersebut merupakan sebuah aspek kegiatan penting dimana anak usia PAUD yaitu 0-6 tahun masih ke dalam tahap praoperasional menurut teori kognitif Piaget yang dimana konstruksi pengetahuan anak berasal dari apa yang dilihat dan dipahami melalui pembiasaan di lingkungannya (Alia \& Irwansyah, 2018; Krogh \& Morehouse, 2014; Ramdhani et al., 2019; Smith, 2005). Setiap pembelajaran yang diterima oleh anak menjadi kunci dalam mencapai aspek perkembangan. Keenam aspek perkembangan tersebut adalah 
perkembangan fisik motorik, sosial emosional, agama dan moral, seni, kognitif dan Bahasa (Ilhami et al., 2019; Pebriana, 2017).

Penerapan pembelajan untuk mencapai keenam aspek perkembangan saat ini terhambat dikarenakan pandemic covid-19. Penerapan pembatasan aktivitas yang dilakukan oleh pemerintah melalui kebijakan lockdown untuk menekan penyebaran pandemi virus Covid-19 memaksa aktivitas pembelajaran untuk anak dilaksanakan di rumah. Aktivitas kegiatan anak dirumah dengan kebiasaan di pagi hari pergi bersekolah membutuhkan proses perubahan aktivitas belajar baru dengan mengedepankan peran dari orang tua dalam penerapan pembelajaran. Biasanya pembelajaran diberikan sepenuhnya kepada guru di sekolah dalam mendidik anak. Akan tetapi sekarang setelah adanya wabah covid-19 kemudian mengharuskan orang tua sebagai guru dan juga sekolah bagi anak (Khadilkar et al., 2020). Proses aktivitas anak pada masa lockdown bervariasi, hal ini dikarenakan setiap anak memiliki aktivitasnya sendiri Ketika di rumah.

Seperti halnya terjadi di Kabupaten Lombok Timur. Penerapan lockdown berimbas pada kegiatan pembelajaran bagi anak. Semua Lembaga PAUD yang bernaung dibawah kemendikbud maupun Kemenag mengalihkan proses pembelajaran di rumah. Berbagai aktivitas anak dalam mengganti aktivitas selama di sekolah yang akan membuat anak tidak mengalami kebosanan Ketika di rumah. Selain itu, proses pembelajaran anak juga diharapkan akan selalu membuat anak mengingat sekolah mereka melalui aktivitas pembelajarannya. Guru sebagai penanggungjawab proses kegiatan pembelajaran harus mampu mengkontrol perkembangan anak Ketika aktivitas pembelajaran diterapkan di rumah sehingga nantinya setiap anak tetap mendapatkan catatan dari perkembangannya. Penelitian tentang implementasi pembelajaran selama lockdown dan penerapan pembelajarannya menjadi pengamatan penting yang harus diamati selama proses lockdown dan penerapan belajar di rumah dilaksanakan.

Pengaplikasian belajar selama pandemic pada Lembaga PAUD menjadi dasar dalam penelitian ini. Tujuan dari penelitian ini adalah untuk melihat berbagai macam metode pembelajaran untuk anak yang diterapkan oleh Lembaga PAUD selama masa pandemic Covid-19. Selain itu juga penelitian ini bertujuan juga untuk melihat manfaat penerapan metode pembelajaran selama belajar di rumah untuk anak PAUD yang diterapkan oleh Lembaga PAUD sehingga nantinya mampu untuk mengembangkan berbagai aspek perkembangan anak.

\section{METODOLOGI}

Ditinjau dari jenis datanya, maka penelitian yang digunakan adalah penelitian kualitatif. Jenis Pendekatan dari penelitian kualitatif yang digunakan adalah dengan pendekatan deskriptif. Jenis penelitian deskriptif kualitatif yang digunakan pada penelitian ini untuk menuturkan pemecahan masalah yang ada dengan berdasarkan data-data. Penelitian deskriptif kualitatif ini untuk memperoleh informasi dan hasil dari implementasi pembelajaran di PAUD pada masa lockdown. Subyek penelitian ini adalah Lembaga PAUD baik yang berada dibawah naungan kemendikbud dan juga PIAUD dibawah naungan kemenag:

Teknik pengumpulan data adalah dengan menggunakan menggunakan observasi atau pengamatan terhadap aktivitas Lembaga, anak dan orang tua di masa lockdown. Teknik pengumpulan data lainnya adalah Teknik wawancara kepada guru dan juga orang tua tentang aktivitas anak selama proses lockdown. Selain itu pula teknik pengumpulan datanya dengan kegiatan dokumentasi. Instumen pengumpulan data yang digunakan adalah human instrumen atau peneliti sendiri yang berfungsi menetapkan fokus penelitian, memilih informan sumber data, pengumpulan data dan analisis data serta melakukan kesimpulan. Instumen lainnya adalah pedoman wawancara dan juga lembar observasi. 
Uji keabsahan data untuk penelitian ini didasarkan dengan empat kriteria yaitu derajat kepercayaan (uji credibility), Keteralihan (Uji Transferability), kebergantungan (dependability) dan kepastian (confirmability)(Colliver, 2016; Khaironi, 2017). Selain pengujian, keabsahan data dalam penelitian ini diperoleh melalui teknik triangulasi. Teknik triangulasi sumber, teknik triangulasi metode dan teknik triangulasi teori. Teknik triangulasi metode yaitu pengumpulan data yang bersumber dari hasil pengamatan dan hasil wawancara. Hasil pengamatan berasal dari proses observasi yang dilakukan pada aktivitas anak dan di sekolah, sedangkan wawancara berasal dari guru, kepala sekolah dan juga orang tua untuk mengetahui sejauh mana aktivitas kegiatan pembelajaran selama pandemic covid-19. Analisis data yang dilakukan apabila data empiris yang diperoleh adalah data kualitatif. Data kualitatif berwujud kata-kata dan bukan rangkaian angka. kegiatan analisis data dilakukan melalui tiga alur kegiatan yang terjadi secara bersamaan yaitu reduksi data, penyajian data, dan penarikan kesimpulan/verifikasi. Terjadi secara bersamaan berarti berarti reduksi data, penyajian data, dan penarikan kesimpulan atau verifikasi sebagai sesuatu yang saling menjaling yang merupakan proses siklus dan interaksi pada saat sebelum, selama, dan saat pengumpulan data (Aqüicultura et al., 2018; Colliver, 2016; Ramdhani et al., 2019) untuk mendeskripsikan alur penelitian yang dilaksanakan dideskripsikan pada gambar berikut ini:

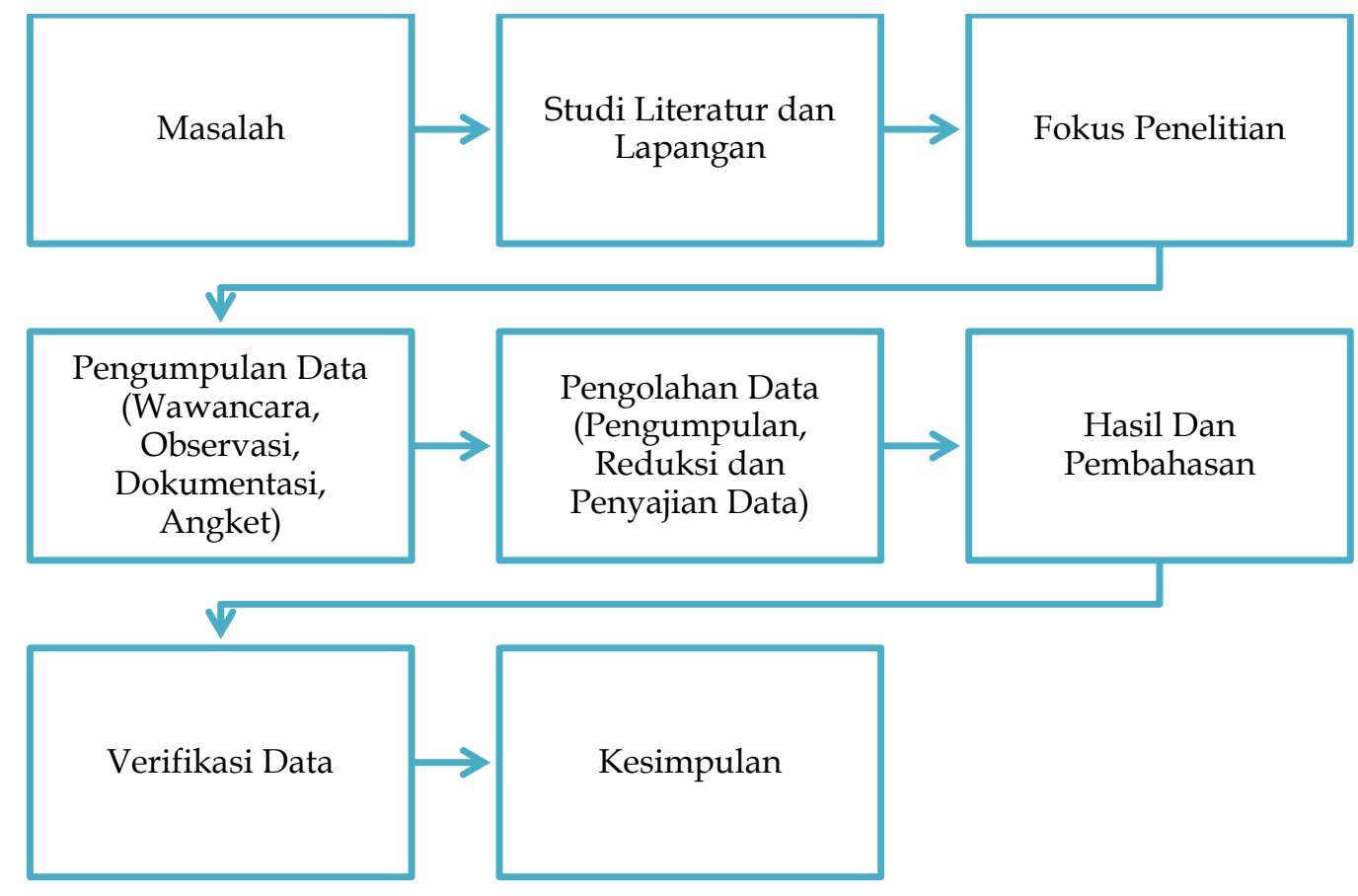

Gambar 1. Desain Penelitian

\section{HASIL DAN PEMBAHASAN}

\section{Hasil Penelitian}

Penerapan proses kegiatan pembelajaran di rumah bagi anak-anak PAUD yang disebabkan oleh kebijakan lockdown dari pemerintah guna mencegah persebaran virus covid19 memberikan beberapa penerapan pembelajaran untuk PAUD di kabupaten Lombok Timur. Berdasarkan hasil observasi dan wawancara yang dilaksanakan dengan rincian subyek wawancara adalah kepala sekolah, guru dan orang tua, maka didapatkan alur penerapan pembelajaran selama masa isolasi atau lockdown di Kabupaten Lombok Timur diantaranya adalah (A) penugasan; (B) Home Visit; dan (C) Laporan Kegiatan Harian anak

Hasil implementasi proses pembelajaran yang pertama adalah penugasan. Proses penugasan ini dilaksanakan dengan memberikan Tugas kepada anak-anak berupa Lembar Kerja anak. Proses pembelajaran anak dilakukan melalui aktivitas kegiatan yang dilakukan 
selama penugasan tersebut. Proses penerapan penugasan ini untuk memberikan aktivitas kepada anak selama masa belajar di rumah berjalan. Sistem penugasan yang dilakukan adalah dengan memberikan buku-buku tema sesuai dengan materi ajar yang sedang berjalan. Materi penugasan yang diberikan diantaranya tema "Pekerjaan, alat-alat komunikasi". Penerapan pembelajaran di rumah dengan penugasan memberikan peran orang tua dalam mendampingi anak selama proses pembelajarannya.

Selain penugasan, proses pembelajaran yang dilakukan semasa lockdown adalah proses Home Visit. Memaksimalkan monitoring kegiatan pembelajaran selama terjadinya lockdown adalah dengan melakukan monitoring dan berkunjung langsung untuk mengetahui proses aktivitas pembelajaran anak Ketika di rumah. Proses Home Visit ini menjadi penting dikarenakan salah satu cara agar aspek perkembangan anak bisa terus dimonitor sehingga aktivitasnya berhasil terlaksana dengan baik. Berdasarkan hasil wawancara yang telah dilakukan didapatkan pelaksanaan Home Visit menjadi alternatif dalam memonitoring perkembangan anak selama di rumah sehingga kegiatan anak dan peran orang tua dalam membimbing anak selama belajar di rumah bisa tercapai. Fungsi orang tua untuk membimbing, mendidik dan mengajar anak selama di rumah bisa terlihat dan kelekatan orang tua dengan anak semakin baik.

Proses penerapan pembelajaran lainnya adalah laporan aktivitas kegiatan anak. Kemajuan teknologi menjadi dasar dalam penerapan aktivitas proses pembelajaran anak di rumah melalui kegiatan laporan kegiatan harian anak oleh orang tua. Pemberian laporan kegiatan harian anak selama proses belajar di rumah. Laporan kegiatan harian orang tua kepada pihak sekolah didasari oleh aktivitas anak yang di susun oleh pihak sekolah agar enam aspek perkembangan anak berjalan dengan baik. Semua proses yang telah diagendakan oleh sekolah melalui orang tua sebagai pelaksana dan memberikan laporan kepada pihak sekolah tentang aktivitas anak selama proses pembelajaran.

Berdasarkan hasil pengumpulan data melalui proses wawancara, angket dan observasi yang dilaksanakan maka didapatkan hubungan dari tiga penerapan proses pembelajaran selama covid-19 yang dideskripsikan dari skema gambar 1 dibawah ini:

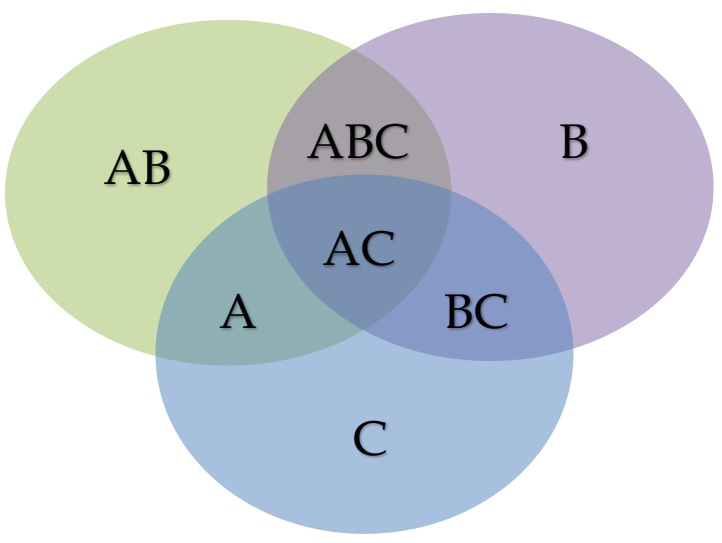

\section{Gambar 2. Skema Impelementasi Pembelajaran Pada Masa Lockdown}

Berdasarkan gambar 1 tentang skema implementasi pembelajaran pada masa lockdown, maka dapat dijelaskan makna dari skema tersebut adalah poin A merupakan aktivitas dalam bentuk penugasan, poin B merupakan implementasi dalam bentuk Home Visit, dan poin $\mathrm{C}$ menjelaskan tentang laporan kegiatan harian. Skema tersebut kemudian menjadi kombinasi pelaksanaan implementasi pembelajaran dari 2 maupun 3 aktivitas. Huruf $\mathrm{AB}$ merupakan kombinasi proses pembelajaran dengan memberikan penugasan dan Home Visit, AC adalah proses penerapan implementasi pembelajaran melalui aktivitas penugasan dan laporan kegiatan harian anak, sedangkan BC mendeskripsikan aktivitas pembelajaran anak di rumah melalui pelaksanaan Home Visit dan laporan kegiatan harian. Pelaksanaan aktivitas paling maksimal adalah mengkombinasikan ketiga aktivitas tersebut 
adalah $\mathrm{ABC}$ yang semua aktivitas implementasi mulai dari penugasan, Home Visit, dan laporan kegiatan harian anak dilaksanakan. Berdasarkan skema implementasi aktivitas di rumah tersebut, berdasarkan hasil pengumpulan data melalui wawancara dan angket dari 30 sekolah di kabupaten Lombok timur maka didapatkan bahwa :

Tabel 1. Sebaran Implementasi Pembelajaran Pada Masa Lockdown di Kabupaten Lombok Timur

\begin{tabular}{|c|l|c|c|}
\hline No & \multicolumn{1}{|c|}{ Skema Implementasi } & Jumlah Sekolah & Persentase (\%) \\
\hline 1 & A (Penugasan) & 10 & 33,33 \\
\hline 2 & B (Home Visit) & 2 & 6,67 \\
\hline 3 & C (Laporan Kegiatan Harian) & 8 & 26,67 \\
\hline 4 & AB (Penugasan \& Home Visit) & 2 & 6,67 \\
\hline 5 & AC (Penugasan \& Laporan Kegiatan Harian) & 3 & 10 \\
\hline 6 & BC (Home Visit dan Laporan Kegiatan Harian) & 4 & 13,33 \\
\hline 7 & $\begin{array}{l}\text { ABC (Penugasan, Home Visit, Laporan } \\
\text { Kegiatan Harian) }\end{array}$ & 1 & 3,33 \\
\hline
\end{tabular}

Berdasarkan tabel 1 tersebut didapatkan bahwa, Lembaga dari 30 lembaga PAUD yang digunakan sebagai sampel didapatkan bahwa 10 sekolah atau sekitar 33, 33\% Lembaga sekolah yang proses implementasi pembelajaran hanya melalui penugasan (A), sedangkan Home Visit (B) sebanyak 2 lembaga atau sekitar 6,67\%, 8 lembaga dengan persentase 26,67 \% yang implementasi pembelajaran di rumah menggunakan Laporan kegiatan harian anak (C), 2 lembaga atau 6,67\% yang melaksanakan penerapan aktivitas pembelajaran menggunakan Penugasan dan Home Visit (AB), 3 lembaga dengan persentase $10 \%$ yang menerapkan penugasan dan laporan kegiatan harian (AC), dan 1 lembaga dengan persentase 3,33\% yang menerapkan implementasi pembelajaran melalui penugasan, Home Visit, dan laporan kegiatan harian (ABC).

Ketiga aktivitas kegiatan belajar di rumah ini diantaranya pada penugasan yang diberikan oleh pihak sekolah memberikan semangat anak untuk belajar apalagi mendapat bimbingan orang tua. Penerapan proses belajar di rumah ini memberikan sebuah gambaran jelas terkait sejauh mana penerapan pembelajaran di kala pandemic covid-19 ini berlangsung. Selain itu, proses belajar di rumah bagi anak tidak menghambat produktivitas anak dalam mengembangkan berbagai aspeknya. Ada penugasan yang diberikan dalam pengerjaan Lembar Kerja Anak, Memberikan kebebasan kepada orang tua untuk memonitoring dan memberikan aktivitas sendiri kepada anak, serta melalui home visit pihak sekolah mampu memonitoring perkembangan anak dengan baik. Kegiatan pelaksanaan pembelajaran tersebut, terlihat dalam pelaksanaan kegiatan yang dilaksanakan pada gambar dibawah ini :
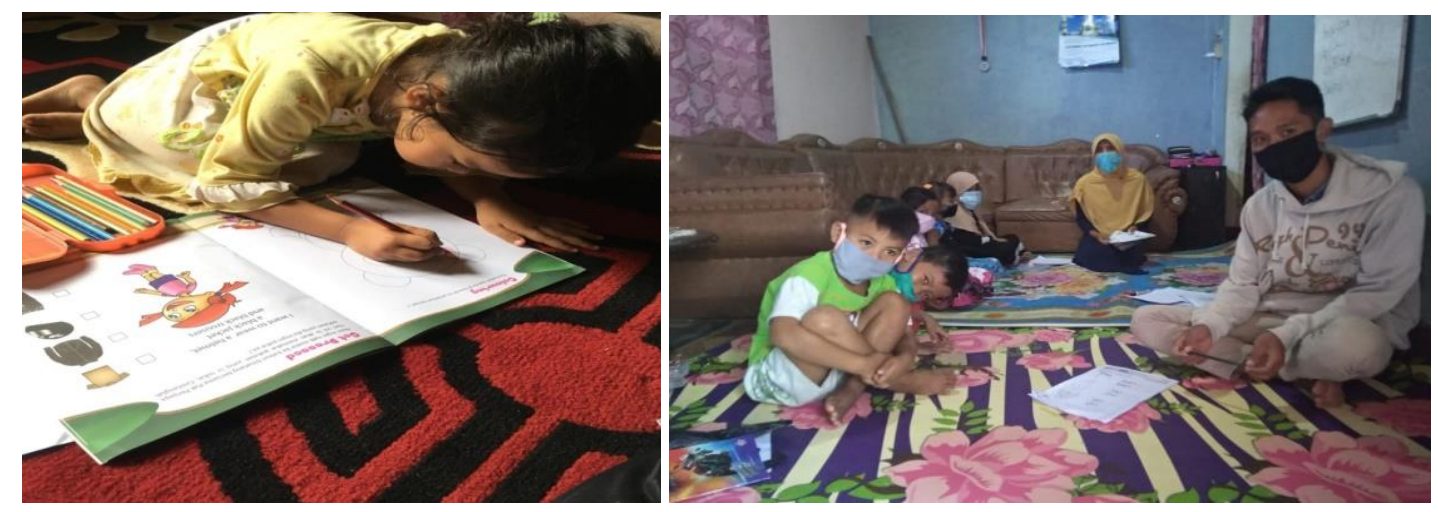

Gambar 3. Kegiatan belajar di rumah melalui kegiatan penugasan dan Home Visit Guru sekolah pada masa pandemic Covid-19 


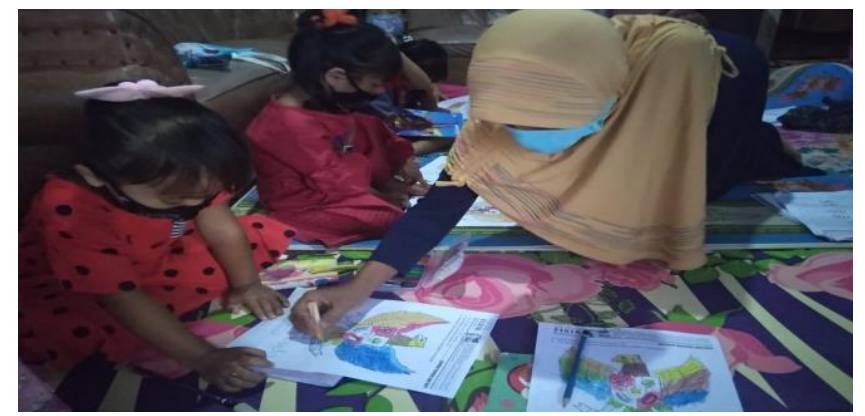

\section{Gambar 4. Pendampingan Orang Tua dalam implementasi Belajar di Rumah}

Ketiga gambar diatas menunjukkan ketiga implementasi pembelajaran yang digunakan. Ketiga implementasi pembelajaran tersebut adalah penugasan, home visit dan pendampingan orang tua. Proses pembelajaran di masa Pandemic Covid-19 tersebut sehingga berbagai implementasi pembelajaran selama di rumah sudah di terapkan dengan tetap menjaga penerapan jaga jarak serta penggunaan masker dalam penerapan implementasi pembelajarannya.

\section{Pembahasan}

Penerapan implementasi pembelajaran pada masa lockdown yang disebabkan oleh pandemi Covid-19 di kabupaten Lombok Timur terpola menjadi tiga proses pelaksanaan pembelajaran. Pelaksanaan pembelajaran pertama adalah penugasan, Home Visit dan laporan kegiatan harian anak. Proses implementasi penerapan pembelajaran selama di rumah tidak hanya menggunakan satu kegiatan saja bahkan menggunakan 2 sampai 3 macam implementasi kegiatan pembelajaran. Implementasi tersebut dilaksanakan berdasarkan lokasi sekolah dan ketersediaan sarana dan prasarana yang ada. Misalkan saja dari perkembangan teknologi, ketersediaan Tenaga pendidik, peran orang tua dan juga proses kegiatan komunikasi antara guru dan orang tua guna keberhasilan proses implementasi pembelajaran di saat pandemi covid-19 tersebut.

Selama masa lockdown, berdasarkan data yang digunakan, proses penugasan, kegiatan Home Visit, dan juga laporan kegiatan harian anak menjadi solusi penting dalam pelaksanaan proses kegiatan belajar anak selama pandemi covid-19 menjadi sebuah keharusan agar semua aspek perkembangan anak bisa berkembang dengan baik sesuai denga capaian perkembangan anak. Capaian perkembangan anak Ketika wabah pandemi harus terus termonitor dikarenakan keterbatasan proses aktivitas anak. Orang tua dan guru menjadi aspek penting dalam keberhasilan perkembangan anak selama masa lockdown melalui proses kolaborasi pembelajaran di rumah (Angus, 2020; Khadilkar et al., 2020). Peran dari Lembaga sekolah sebagai akomodir pembelajaran harus mengacu kepada proses pelaksanaan, kebutuhan anak dan juga ada kegiatan terstruktur yang diberikan oleh guru melalui aktivitas-aktivitas pembelajaran dan penugasan selama pandemi ini.

Pelaksanaan implementasi pembelajaran selama lockdown di kabupaten Lombok timur tidak terlepas dari peran serta orang tua, guru, stakeholder sekolah dalam berkomunikasi dan menjamin kebutuhan anak dalam belajar terpenuhi. Selama pandemi covid-19 ini, penerapan proses pembelajaran melalui proses penugasan Home Visit, laporan aktivitas anak Ketika di rumah akan mampu menjadi sebuah dasar dalam pelaksanaan kesuskesan belajar anak di rumah. Penugasan dan Home Visit mampu sebagai control dalam mengetahui aktivitas anak selama proses pembelajaran (Foster et al., 2016; Lukie et al., 2014; “Drzal \&Dearing," 2017).

Peran orang tua selama masa lockdown ini menjadi peran utama. Orang tua sebagai tempat pertama yang mengetahui perkembangan anak menjadi control dan guru anak selama di rumah. Bustan et al., (2016) menjelaskan bahwa orang tua adalah inti dari perkembangan anak dikarenakan orang tua yang paling sering interaksi, komunikasi, dan 
monitoring aktivitas yang dilakukan anak selama proses belajar dan bermainnya di rumah (Nuraeni, 2016; Solari, 2014). Melalui proses laporan aktivitas anak yang dilakukan oleh orang tua kepada pihak sekolah terutama guru kelas menjadikan semua kegiatan anak dapat terlaporkan dan termonitor oleh guru dan orang tua bisa menjadi guru di rumah untuk anak-anaknya.

Proses pelaksanaan implementasi pembelajaran dikala pandemi covid-19 ini terdapat 3 aspek penting yang menjadi catatan yang diantaranya adalah : (1) inovasi pembelajaran tetap berjalan dengan memanfaatkan teknologi sehingga proses kegiatan belajar bisa terakomodir dengan baik; (2) dikala pandemi covid-19 orang tua membuatkan wadah bermain dan belajar anak agar tidak cepat bosan selama belajar di rumah, terkadang rasa bosan dari anak menjadi sebuah hal yang harus terus didasarkan dalam proses pembelajaran di rumah; dan (3) anak-anak akan lebih banyak untuk menggunakan handphone/smartphone dalam proses aktivitasnya, oleh karena itu pengawasan orang tua menjadi sebuah kunci untuk dapat melaksanakan aktivitas anak berjalan dengan baik (Bi et al., 2019; Cabrera et al., 2018; Khadilkar et al., 2020; Satya Yoga et al., 2015; Shereen et al., 2020)

Orang tua, guru, stakeholder Lembaga PAUD memiliki andil besar dalam menciptakan pembelajaran yang positif selama pandemi ini. Kegiatan-kegiatan di rumah dengan koordinasi guru dan orang tua menjadikan kegiatan anak di rumah lebih bermakna. Kebermaknaan anak belajar akan memberikan dampak dalam mengurangi penggunaan gadget selama proses lockdown ini. Selama masa belajar di rumah, anak akan selalu memanfaatkan waktu yang ada untuk bermain gadget. Dengan bermain gadget beban orang tua akan semakin berkurang selama anak belajar di rumah, akan tetapi hal inilah yang akan menciptakan kemalasan bagi anak dalam beraktivitas dan belajar sehingga perkembangan anak akan terhambat. penerapan gadget atau pemanfaatan teknologi di rumah akan berakibat buruk bagi perkembangan anak tanpa adanya pendampingan dari orang tua, sehingga koordinasi orang tua dan guru dalam pembelajaran serta sistematis guru dalam Menyusun aktivitas anak dalam belajar menjadi kunci utama dalam tujuan untuk mencapai perkembangan anak yang maksimal (Alia \& Irwansyah, 2018; Amini, 2015; Martin \& Betrus, 2019; Pagestu, 2017; Toki \& Pange, 2014)

\section{SIMPULAN}

Proses implementasi pembelajaran di masa lockdown sehingga penerapan belajar di rumah pada anak usia dini terletak pada aktivitas yang di susun oleh pihak sekolah yang kemudian di implementasikan oleh anak dengan bimbingan orang tua. Terdapat tiga aktivitas utama dalam pelaksanaan pembelajaran. Ketiga aktivitas itu adalah penugasan dari pihak sekolah, home visit yang dilakukan oleh guru, dan laporan kegiatan harian yang dilaksanakan oleh orang tua melalui program kegiatan yang disusun oleh guru. Penerapan implementasi pembelajaran selama covid-19 ini di dominasi oleh penugasan dan laporan kegiatan harian, meskipun begitu beberapa sekolah juga menerapkan kolaborasi ketiga aktivitas tersebut. Selama penerapan belajar di rumah, peran orang tua juga mempengaruhi aktivitas anak sehingga kolaborasi antara guru dan orang tua dalam proses belajar bisa berjalan dengan baik serta pengawasan terhadap aktivitas anak guna mengawasi aktivitas anak selama proses aktivitas belajar di rumah. Implementasi pembelajaran selama pandemi pada Lembaga PAUD identik dengan pelaksanaan proses aktivitas yang luas dan mengedepankan aktivitas anak yang membutuhkan pembelajaran yang tidak membosankan dan tidak menghilangkan inti dari belajar pada anak usia dini itu sendiri.

\section{UCAPAN TERIMAKASIH}

Terima kasih kepada sekolah-sekolah mitra yang telah memberikan informasi dan data terkait aktivitas sekolah atau Lembaga PAUD selama pelaksanaan belajar di rumah yang diakibatkan oleh Wabah Virus Covid-19. TK Hamzanwadi, TK Ummi Adniyah, TK 
PGRI Labuhan Haji, PAUD Al-Khair Masbagik dan beberapa sekolah mitra lainnya yang tidak bisa disebutkan Namanya satu persatu. Terima kasih kepada Universitas Hamzanwadi, tim peneliti, dan juga sumber-sumber data yang telah dengan sukarela memberikan informasi terkait kebutuhan data tentang aktivitas anak selama pandemi covid19 ini.

\section{DAFTAR PUSTAKA}

Alia, T., \& Irwansyah. (2018). Pendampingan Orang Tua pada Anak Usia Dini dalam Penggunaan Teknologi Digital. A Journal of Language, Literature, Culture and Education, 14(1), 65-78. https://doi.org/10.19166/pji.v14i1.639

Amini, M. (2015). Profil Keterlibatan Orang Tua dalam pendidikan anak usia TK. Jurnal $\begin{array}{llll}\text { Ilmiah VISI PPTK } & \text { 9-20. }\end{array}$ http://journal.unj.ac.id/jurnalfip/index.php/visi/article/view/7/8

Angus, D. C. (2020). Optimizing the Trade-off Between Learning and Doing in a Pandemi. Jama, 15261. https:// doi.org/10.1001/jama.2020.4984

Bi, K., Chen, Y., Zhao, S., Ben-Arieh, D., \& Wu, C. H. (John). (2019). Modeling learning and forgetting processes with the corresponding impacts on human behaviors in infectious disease epidemics. Computers and Industrial Engineering, 129(xxxx), 563-577. https:// doi.org/10.1016/j.cie.2018.04.035

Bustan, R., Nurfadilah, \& Fitria, N. (2016). Pelatihan Optimalisai Tumbuh Kembang Anak pada Orangtua Anak Usia Dini. Jurnal AL-AZHAR INDONESIA SERI HUMANIORA, 3(3), 274-282. https:// doi.org/10.36722/sh.v3i3.214.

Cabrera, N. J., Volling, B. L., \& Barr, R. (2018). Fathers Are Parents, Too! Widening the Lens on Parenting for Children's Development. Child Development Perspectives, 12(3), 152-157. https:// doi.org/10.1111/cdep.12275

Colliver, Y. (2016). Mothers' Perspectives on learning through Play in the Home. Australasian Journal of Early Childhood, 41(1), 4-12. https:/ / doi.org/10.1177/183693911604100102

Covid19.go.id. (2020). No Title. Kementerian Kesehatan Republik Indonesia. https://covid19.go.id

Foster, T. D., Froyen, L. C., Skibbe, L. E., Bowles, R. P., \& Decker, K. B. (2016). Fathers' and mothers' home learning environments and children's early academic outcomes. Reading and Writing, 29(9), 1845-1863. https:// doi.org/10.1007/s11145-016-9655-7

Ilhami, B. S., Fitri, B. F. H., \& Ramdhani, S. (2019). Permainan Kuda Bisik Untuk Meningkatkan Kemampuan Pembendaharaan Kosakata Anak Usia 5-6. Cakrawala Dini; Jurnal Pendidikan Anak Usia Dini, 10(2), 101-108. https:// doi.org/10.21107/pgpaudtrunojoyo.v6i2.6151.

Kementerian Sekretariat Negara Republik Indonesia. (2020). Peraturan Pemerintah Nomor 21 Tahun 2020 tentang Pembatasan Sosial Berskala Besar Dalam Rangka Percepatan Penanganan Coronavirus Disease 2019/COVID-19. 1(1), 022868 A-022846 A.

Keppres. (2020). Keputusan Presiden (Keppres) Nomor 11 Tahun 2020 tentang Penetapan Kedaruratan Kesehatan Masyarakat Covid-19. Keputusan Presiden, 031003, 1-2.

Khadilkar, H., Ganu, T., \& Seetharam, D. P. (2020). Optimising Lockdown Policies for Epidemic Control using Reinforcement Learning. http:/ / arxiv.org/abs/2003.14093

Khaironi, M. (2017). Penanaman sikap beragama dan moral anak usia dini di TKIT Salman Al Farisi 2. JPPM (Jurnal Pendidikan Dan Pemberdayaan Masyarakat), 4(2), 166-179. https:// doi.org/10.21831/jppm.v4i2.9787

Kim, M. S. (2014). The multi-literacy development of a young trilingual child: Four leading literacy activities from birth to age six. European Early Childhood Education Research Journal, 22(2), 154-168. https:/ / doi.org/10.1080/1350293X.2014.883718

kompas. (2020). who umumkan virus corona sebagai pandemi global Kompas.Com. https://www.kompas.com/global/read/2020/03/12/001124570/who-umumkanvirus-corona-sebagai-pandemi-global?page $=$ all 
Krogh, S., \& Morehouse, P. (2014). The Early Childhood Curriculum : Inquiry Learning Through Integration. https://doi.org/10.4324/9780203521625.

Lukie, I. K., Skwarchuk, S. L., LeFevre, J. A., \& Sowinski, C. (2014). The Role of Child Interests and Collaborative Parent-Child Interactions in Fostering Numeracy and Literacy Development in Canadian Homes. Early Childhood Education Journal, 42(4), 251259. https://doi.org/10.1007/s10643-013-0604-7

Martin, F., \& Betrus, A. K. (2019). Digital Media for Learning. In Digital Media for Learning. https://doi.org/10.1007/978-3-030-33120-7

Mussardo, G. (2019). 済無No Title No Title. In Statistical Field Theor (Vol. 53, Issue 9). https://doi.org/10.1017/CBO9781107415324.004

KEmendikbud. (2020). bEdaran aktivitas pembelajaran selama pandemi covid-19. 4-6.

Nuraeni, A. (2016). Peran Orang Tua dalam Pengembangan Literasi Dini Anak Kelompok B di Gugus 7 Mangunan Dlingo Bantul. Jurnal Pendidikan Anak Usia Dini, 3, 245-256. http://journal.student.uny.ac.id/ojs/index.php/pgpaud/article/viewFile/1256/1131

Pagestu, R. (2017). Ratna Pangastuti. Fenomena Gadget Dan Perkembangan Sosial Bagi Anak Usia Dini.

Pebriana, P. H. (2017). Jurnal Obsesi: Jurnal Pendidikan Anak Usia Dini Analisis Penggunaan Gadget terhadap Kemampuan Interaksi Sosial. Jurnal Pendidikan Anak Usia Dini, 1(1), 8. https://doi.org/10.31004/obsesi.v1i1.26

Ramdhani, S., Yuliastri, N. A., Sari, S. D., \& Hasriah, S. (2019). Penanaman Nilai-Nilai Karakter melalui Kegiatan Storytelling dengan Menggunakan Cerita Rakyat Sasak pada Anak Usia Dini. Jurnal Obsesi: Jurnal Pendidikan Anak Usia Dini, 3(1), 153. https://doi.org/10.31004/obsesi.v3i1.108

Satya Yoga, D., Suarmini, N. W., \& Prabowo, S. (2015). Peran Keluarga Sangat Penting dalam Pendidikan Mental, Karakter Anak serta Budi Pekerti Anak. Jurnal Sosial Humaniora, 8(1), 46. https://doi.org/10.12962/j24433527.v8i1.1241

Setneg RI. (2003). Undang-Undang Republik Indonesia Nomor 20 Tahun 2003 Tentang Sistem Pendidikan Nasional. Setneg RI.

Shereen, M. A., Khan, S., Kazmi, A., Bashir, N., \& Siddique, R. (2020). COVID-19 infection: Origin, transmission, and characteristics of human coronaviruses. Journal of Advanced Research, 24, 91-98. https:/ / doi.org/10.1016/j.jare.2020.03.005

Smith, susan sperry. (2005). Early Childhood Mathematics (3rd Edition).

Solari, E. (2014). Longitudinal prediction of 1st and 2nd grade English oral reading fluency in ELL. Journal of Adolescence, 74(4), 274-283. https://doi.org/10.1002/ pits

The Wiley Handbook of Early Childhood Development Programs, Practices, and Policies. (2017). In The Wiley Handbook of Early Childhood Development Programs, Practices, and Policies. https:// doi.org/10.1002/9781118937334

Toki, E. I., \& Pange, J. (2014). Ict Use in Early Childhood Education: Storytelling. Tiltai, 66(1), 183-192. https://doi.org/10.15181/tbb.v66i1.786

Trubus. (2020, March). Pemerintah Tetapkan Status Wabah Covid-19 Sebagai Bencana Nasional. Trubus.

Uscher-Pines, L., Schwartz, H. L., Ahmed, F., Zheteyeva, Y., Meza, E., Baker, G., \& Uzicanin, A. (2018). School practices to promote social distancing in K-12 schools: Review of influenza pandemi policies and practices. BMC Public Health, 18(1), 1-13. https:// doi.org/10.1186/s12889-018-5302-3

Wuryandani, W., \& Senen, A. (2018). Implementasi pemenuhan hak anak melalui sekolah ramah anak. Jurnal Civics: Media Kajian Kewarganegaraan, 15(1), 86-94. https://doi.org/10.21831/jc.v15i1.19789.

Yuliastri, N. A., \& Ramdhani, S. (2018). Pengembangan Pembelajaran Tematik Integratif Untuk Meningkatkan Nilai Karakter Anak Usia Dini. Jurnal Golden Age, 2(01), 44-58. http:/ / dx.doi.org/10.29408/goldenage.v2i01.898 